\title{
Septic Arthritis in Dogs: A Retrospective Study of 20 Cases (2000-2002)
}

\author{
K. SOONTORNVIPART, P. KOHOUT, P. PROKS
}

Department of Surgery and Orthopaedics, Small Animal Clinic, Faculty of Veterinary Medicine, University of Veterinary and Pharmaceutical Sciences, Brno, Czech Republic

\author{
Received April 23, 2003
}

Accepted September 22, 2003

\begin{abstract}
Soontornvipart K., P. Kohout, P. Proks: Septic Arthritis in Dogs: A Retrospective Study of 20 Cases (2000-2002). Acta Vet. Brno 2003, 72: 405-413.

Septic arthritis might be difficult to diagnose due to nonspecific clinical signs and radiological findings in early stage of the disease. An early diagnosis is important for achieving favorable prognosis. Diagnosis of septic arthritis was confirmed by physical and orthopedic examinations, evaluation of radiographs and synovial fluid analysis including leukocyte and neutrophil counts, cytological examination and bacterial culture. Sensitivity and specificity of these diagnostic methods were retrospectively evaluated from clinical records of 18 dogs with 20 septic joints treated in the Department of Surgery and Orthopaedics in Small Animal Clinic at University of Veterinary and Pharmaceutical Sciences Brno from January 2000 till the end of 2002 .

Our patients affected by septic arthritis belonged to medium to large breed dogs. Infection of 13 septic joints in 11 patients was spread by hematogenous route, whereas the other 7 joints (in 7 patients) were infected during surgical procedure or after joint injury. Recurrence of hematogenous joint infection was found in 2 patients. In all the patients, exercise intolerance and painful reaction in affected joint were detected. Cultures of synovial fluid samples were positive in only 8 cases. Staphylococcus intermedius, Streptococcus spp., Enterococcus Group 3 , Pseudomonas aeruginosa, coagulase-negative staphylococcus and Bacillus spp. were isolated. Radiographic findings included joint effusion, osteoarticular destruction and new bone proliferation and these were not specific for septic arthritis.

We found that diagnostic methods used in this study showed high sensitivity but low specificity. Complex diagnostic approach including physical, orthopaedic and radiographic examinations, and synovial fluid evaluation should be performed to achieve correct diagnosis and effective treatment.

Joint infection, radiography, synovial fluid, diagnosis, treatment
\end{abstract}

Inflammatory joint diseases caused by infection or immunological factors are not rare in small animal practice but they occur infrequently. Generally, the septic arthritis caused by bacterial infection is very rare (Schrader 1982). Bacterial infections of joints usually begin suddenly and develop rapidly into an acute suppurative arthritis. Pain, lameness, and limitation of joint motion occur along with the classic signs of inflammation, swelling, redness, heat, and tenderness. Joint effusion is present early, thus providing a very important diagnostic tool. Suppurative arthritis due to hematogenous spread is unusual in the dog and, when seen, is most often in the young or debilitated animal. The severity of joint destruction depends on the type of bacteria and the duration of infection. Each type of bacteria can cause arthritis in a different way. Streptococci and staphylococci produce a large number of extracellular and cell-associated molecules such as kinases and peptidoglycans. They activate plasminogen and result in plasmin, which removes chondroprotein from cartilage matrix (Liu et al. 2001). Corynebacterium pyogenes infection causes severe pannus formation (granulation) over cartilaginous surfaces, whereas Clostridium species can elaborate collagenase. Although many pathogens have been incriminated in joint infections such as Prevotella bivia (Laho and Kotilaien 2001), Moraxella kingae (Kingella kingae)(Esteve 
et al 2001), ehrlichiosis (Cowell et al 1988), Erysipelothrix rhusiopathiae, Yersinia, Chlamydia (May 1995), Peptostreptococcus spp., Clostridium spp., Bacteroides spp. and Propionibacterium spp. (Hudgin et al. 1992) were reported, the ones that most commonly attack these tissues are Staphylococcus aureus, hemolytic Streptococcus, Pseudomonas aeruginosa, and Klebsiella spp. (Abuekteis et al. 1996; Egan et al. 1999; Hultgren et al. 1998). The infecting organism reaches the joint tissue (by hematogenous spread) as a result of a primary septicemia from a bacterial endocarditis, pneumonia, or abscess in another part of the body (Bennett and Taylor 1988; Egan et al. 1999). Furthermore, septic arthritis may develop after arthrocenthesis or injection especially in the patient with rheumatoid arthritis or with preexisting joint diseases (Hultgren et al. 1998; Laho and Kotilaien 2001; Liu et al. 2001; Mclnnes et al. 1998). The most common entry is a surgical wound (during surgical procedure) or a direct penetrating wound (e.g. bite wounds). It was reported that males are almost two and half times more often victims of aggression than females and that the highest incidence of bite wounds was in one- and two-year-old animals (Baranyiová et al. 2003). A penetrating joint wound has the potential to be a permanently disabling injury. Early and effective treatment may be relatively simple, but if septic arthritis develops, effective treatment is difficult. Early diagnosis and treatment are of utmost importance. Nevertheless, when there has been a delay in instituting the proper treatment, the presenting problem may be septic arthritis. Successful results are dependent upon early diagnosis and proper treatment. Penetrating joint injuries treated early by arthrotomy, dèbridement, and irrigation have a better prognosis than those treated several days later since sepsis and potential irreparable damage may be avoided (Piermattei and Flo 1997).

Today, because of the development of specific antibiotic agents and the early aggressive treatment, the complete course of suppurative arthritis is seen less often. It is imperative that the clinician can make an early and accurate diagnosis so that the infection may be treated aggressively and cured before irreversible joint damage takes place (Sakiniene and Collins 2002). This is fortunate because the articular plate has little or no capacity for regenerative healing. With the loss of articular plates, there is usually an extension of granulation from one subchondral area to the other across the joint space. As the granulation ages, it forms collagen scar tissue, and a fibrous ankylosis is the result. The collagen often calcifies as it condenses, followed usually by ossification/ankylosis. In short, if the joint infection progresses to destruction of the articular plate, joint destruction and patient crippling will be the result. The purpose of our study is to present the clinical and laboratory findings associated with septic arthritis in small animal practice and to determine sensitivities of clinical, paraclinical and laboratory signs of septic arthritis.

Table 1

Bacterial culture from synovial fluid

\begin{tabular}{|l|l|l|}
\hline Type of bacteria & Route of infection & Suspected primary source \\
\hline Staphylococcus spp. & Direct route & Infection after arthrotomy: UAP \\
\hline Streptococcus spp. & Direct route & Infection after arthrotomy: CCL \\
\hline Pseudomonas aeruginosa & Direct route & Infection after arthrotomy: CCL \\
\hline Bacillus spp. & Direct route & Trauma after kicking of horse \\
\hline Pseudomonas aeruginosa & Hematogenous route & Endocarditis \\
\hline Streptococcus spp. & Hematogenous route & Not detected \\
\hline Enterococcus & Hematogenous route & Enteritis \\
\hline Staphylococcus coagulase negative & Hematogenous route & Cystitis \\
\hline Corynebacterium striatum $*$ & Hematogenous route & Septicemia, abscess after vaccination \\
\hline
\end{tabular}

* - cultivation positive from sample obtained in private practice two days earlier 


\section{Materials and Methods}

Clinical records of 18 dogs with 20 suspected septic joints, treated at the Department of Surgery and Orthopaedics in Small Animal Clinic, University of Veterinary and Pharmaceutical Sciences Brno, during a threeyear period (from January 2000 till the end of December 2002) were reviewed and evaluated.

Clinical signs were diagnosed and evaluated when the patients were presented with the following clinical conditions:

- fever $\left(>39.2^{\circ} \mathrm{C}\right)$

- pain (localized to the joint) made worse by gentle, passive motion,

- swelling of the involved joint,

- leukocytosis $\left(>17 \times 10^{9} \cdot \mathrm{l}^{-1}\right)$,

- monoarticular involvement.

Lameness was categorized into 3 degrees of severity (mild, moderate, and severe lameness) according to veterinarian's justification. Based on duration of gait abnormality, the lameness was classified as acute $(<1$ week duration) or chronic ( $>1$ month).

Radiographic examinations were performed in 17 patients on the 19 affected joints. In 3 patients, the clinical signs were sufficient to diagnose, so the radiographic examination was not performed. Radiographic changes were interpreted and evaluated by the veterinary radiologist. Radiographic findings were observed as the following changes:

- subchondral bone destruction,

- new bone proliferation,

- joint effusion/soft tissue swelling around the affected joint.

Arthrocentesis was performed aseptically and joint fluid was immediately examined cytologically and microbiologically. The total leukocyte count was determined using the Coulter Counter® (Coulter Electronics Ltd. Harpenden Hearts, England). Synovial fluid was smeared onto the slide and then stained with May-Grünwald and Giemsa-Romanowsky for the differential leukocyte counts. The proportion of neutrophils and other white blood cells were recorded. Synovial fluid was inoculated onto Amies transport medium (CM 425, Oxoid) or Cary-Blair medium (CM 519, Oxoid). Bacterial culture was performed by inoculation of the sample onto Blood agar base (CM 854, Oxoid) and MacConkey agar (CM 7b, Oxoid). All samples were cultured aerobically. All dogs were treated with antibiotics. The follow up and the outcome of treatment were observed and recorded.

\section{Results}

Among the 18 dogs treated at the Department of Surgery and Orthopaedics in Small Animal Clinic, University of Veterinary and Pharmaceutical Sciences Brno, twelve different breeds were presented: German Shepherd (2), Rottweiler (2), Giant Schnauzer (2), Cane Corso (2), Great Dane (2), Labrador Retriever (2), Brasilian Fila (1), Rhodesian Ridgeback (1), Chow Chow (1), Irish Setter (1), Hovawart (1), Bull Terrier (1) and Bulldog (1). Male dogs were affected more commonly (12 dogs) than female (6) dogs. In two dogs (1 male Brasilian Fila and 1 male Giant Schnauzer), the recurrent septic arthritis was diagnosed during the three-year period, therefore our study included 20 septic joints in 18 dogs.

The age of dogs varied from 5 weeks to 10 years, $40 \%$ of patients were young dogs (less than 1 year). Young dogs seem to be affected by hematogenous septic arthritis (7/8). Only 1 young dog had septic arthritis after the surgery. Five septic joints were associated with previous surgical procedures with arthrotomy (4 joints) and arthroscopy (1 joint). Only 1 septic joint in a patient was associated with the previous joint trauma. Hematogenous joint infection was diagnosed in thirteen joints. The primary bacterial sources were presumably associated with abscesses ( 2 joints), bite wounds ( 2 joints), enteritis ( 1 joint), dermatitis and cystitis ( 1 joint) and endometritis after birth ( 1 joint). The primary bacterial source was not identified in 6 joints. In one dog, the unidentified septic arthritis may have been associated with hematogenous infection and/or direct infection as well because this dog has undergone previous joint surgery (2 years before septic joints occurred) but at the time of presentation, septic joint was associated with endocarditis.

In all dogs, septic arthritis was found in one joint (monoarticular). The 20 affected joints comprised of 8 stifle joints, 5 elbow joints, 4 carpal joints, 2 hip joints and 1 tarsal joint. Rectal temperature was recorded in 16 patients and it was increased $\left(>39.2{ }^{\circ} \mathrm{C}\right)$ in 9 patients 
(56\%) (9 joints). Blood leukocyte counts were evaluated in 16 dogs. Leucocytosis $\left(>17 \times 10^{9} \cdot \mathrm{l}^{-1}\right.$ ) was detected only in $31 \%$ samples ( 5 cases). Pain was detected in all patients. Swelling and local hyperthermia of the affected joints were detected in almost all except for two septic hip joints. Lameness was detected in all cases. The degree of lameness was classified into 3 groups: mild (9 joints), moderate ( 8 joints), and severe degree ( 3 joints). Duration of lameness varied from 1 day to 1 year, acute lameness $(<1$ week duration) was detected in 55\% of cases and chronic lameness ( $>1$ week) in 30\% of cases.

Radiographs were performed in 19 joints. In all patients, the radiographic abnormalities included soft tissue swelling or joint effusion (17 joints), subchondral bone destruction (6 joints) and new bone proliferation (11 joints). The subchondral bone destruction was associated with chronic lameness. In one patient, the radiograph was not performed because the clinical signs and synovial fluid examination in this patient were sufficient to perform final diagnosis.

Arthrocentesis was done in all joints. In two joints, small amount of synovial fluid could be collected and it was enough only for cytological evaluation. In 18 synovial fluid samples, total nucleated cell counts from synovial fluid was evaluated and its average was 83.8 $\times 10^{9} \cdot 1^{-1}$ (range of 15.1 to $223.7 \times 10^{9} \cdot 1^{-1}$ ). In $78 \%$ of septic joints, total nucleated cell count in synovial fluid was higher than $50 \times 10^{9} \cdot \mathrm{l}^{-1}$. The proportion of neutrophils in synovial fluid varied from $50 \%$ to $95 \%$. However, in $70 \%$ of samples, the proportion of neutrophils was high (up to $90 \%$ or more). Bacteria (cocci) were detected in four samples.

Bacterial culture results from synovial fluid were positive in 8 samples. In one dog, positive sample cultivation was obtained from private practice 2 days before admission to our clinic. Type of bacteria, route of infection and suspected primary source of bacteria is presented in Table 1 . Probability of positive cultivation was not related to any clinical, paraclinical and laboratory signs of septic arthritis. The most commonly positive cultivation was associated with bacteria detection in synovial fluid (Fisher's test; $p=0.15$ ) and it was related to the dogs with direct route of joint infection (Fisher's test; $p=0.15$ ).

Antibiotic treatments with amoxicillin-clavulanic acid (Synulox®; Augmentin $\left.{ }^{\circledR}\right)$ (14), cephalosporin (Cephaclen $($ ) (2), clindamycin (Antirobe () (2), enrofloxacin (Baytril $囚)(1)$ and amikacin (Amikin $囚)(1)$, have good responses in all cases. In 2 dogs, recurrent arthritis was developed in different joints 3 weeks and 2 years after the first septic arthritis was successfully treated and they have excellent responses to the second-antibiotic treatment. This recurrence of arthritis in these two dogs was categorized as the separate case in this study. In one dog, recurrent septic arthritis in a different joint was identified and the final treatment with azathioprim (Imuran ${ }^{\circledR}$ ) and corticosteroid application was performed. Because this dog had septic arthritis associated with coexistent systemic lupus erythematosus (SLE).

\section{Discussion}

Inflammatory arthritis caused by an infectious agent is not commonly encountered as either a clinical or radiographic entity in small animal practice. Infection can reach the joint by nonhematogenous route, such as a penetrating wound or extension of an infectious process in surrounding bone and soft tissues or surgical procedures (Gál and Nečas 1999; Dvořák et al. 2000; Hulse and Nečas 2002). Hematogenous infection is probably less common than those caused by penetrating injuries (Owens and Ackerman 1978) or surgical procedures (Marchev sky and Read 1999). However, some authors reported that the blood borne septic arthritis is more common than the infections caused by penetrating wounds especially in large breeds such as Great Dane, St. Bernard and German Shepherd Dog (Pederson and Pool 1978; Bennett and Taylor 1988; Bennett and Taylor 1987). In our study, all dogs with septic arthritis were medium to large breed dogs and $70 \%$ 
of them were suspected that the septic arthritis was caused by the hematogenous route whereas only $30 \%$ of them where caused by infection after the joint operation or after direct trauma. Risk of infection by hematogenous route was high in puppies (Bittegeko et al. 1993). In accordance with our study, $87.5 \%$ of young dogs (< 1 year) with septic arthritis were mainly affected by hematogenous route.

Arthritis often appears clinically before radiographic change is presented. In these diseases, the radiographs and MRI do not really assist in the diagnosis; rather they provide later opinions to the nature and degree of the disease present (S trou se et al. 1999). Bacterial arthritis may be confused with other types of arthritis (Owens and Ackerman 1978) due to their similar radiographic abnormalities. However, plain X-rays may be useful to detect associated conditions and to study progression. The progress of the radiological signs depends on the virulence of the organism (Perez 1999). The appearance of the articular cortex and subchondral bone is vital in the differentiation between infectious and noninfectious arthritis, as this area is destroyed early in bacterial arthritis (Owens and Ackerman 1978). In our study all patients had non-specific radiographic changes including joint effusion, and mild to severe degree of osteoarthritis, which cannot be the definitive diagnosis in clinical practice (Nečas and Zatloukal 2001). The new bone proliferation is not commonly found in septic arthritis, however, it can be found in the patients with preexisting osteoarthritic diseases such as hip dysplasia (Too mbs and Nečas 1999), cruciate ligament rupture (Nečas et al. 2000; Zatloukal et al. 2000; Nečas and Zatloukal 2002; Nečas et al. 2002), osteochondrosis (Olsson 1993; Nečas et al. 1999), fragmented coronoid process and ununited anconeal process (Guthrie et al. 1992; Olss on 1993; Wind 1993). More specific changes as subchondral bone destruction were detected only in 6 joints with chronic lameness. In human medicine, nuclear medicine and scintigraphy were always performed in the patients with septic arthritis to determine both the localization and the number of inflammatory foci in all area of the body (Corsten and Van der Meer 1999; Perez 1999). Although scintigraphy with 99Tc-MDP (99Tcmethylene diphosphonate) is not specific and may be normal at the outset, it allows localization of septic arthritis because of radionuclide accumulation in the septic foci owing to an increased blood supply and bone turnover. Gallium scintigraphy and 111Indium scanning are more specific and sensitive than 99Tc-MDP in the detection of active lesion (Bittini et al. 1985) because they have more sensitivity in acute infection because of locally increased vascular permeability and leukocyte migration. However, these techniques are still not available in our practice.

Approximately a half of patients manifest fever, usually in association with an acute lameness. They always present leukocytosis in hemogram. Sterile aspiration of the joint fluid will reveal an increased number of polymorphonuclear leukocytes, from $40 \mathrm{G} \cdot \mathrm{l}^{-1}$ to $50 \mathrm{G} \cdot \mathrm{l}^{-1}$ in early of infection and rising rapidly to $100 \mathrm{G} \cdot \mathrm{l}^{-1}$ or higher depending on the type of organism and the duration and severity of the infection. The synovial fluid glucose is usually reduced (in contrast to blood glucose) owing to its metabolism by massive numbers of polymorphonuclear leukocytes (Dubost et al. 2000). In most joint infections the disease is monoarticular, unlike some of the autoimmune diseases. In our study, we found that in $78 \%$ of patients had leukocyte count more than $50 \mathrm{G} \cdot \mathrm{l}^{-1}$ and percentage of neutrophils in synovial fluid varied from $50 \%$ to more than $95 \%$ in all patients, which may indicate bacterial infection in the joint (Dubost et al. 2000).

Because of the serious implications of delayed diagnosis of septic arthritis, patients with suspected articular infections are usually given empirical antimicrobial therapy based on clinical consideration, cytological and biochemical examination of aspirated joint fluid samples (Goldenberg and Reed 1985). Detection of the causative microorganism remains important to confirm the diagnosis and to guide the antimicrobial regimen (Fink 
and Nelson 1986). However, culture of synovial fluid of patients with suspected septic arthritis, even when performed prior to the initiation of antibiotics, is frequently disappointing (Yagupsky and Press 1997).

Borreliosis serological test was performed to diagnose septic arthritis from the lyme arthritis, which is a multisystemic disorder caused by infection with Borrelia burgdorferi. This subacute arthritis appears to be caused by the host inflammatory response to invasion of joints by the spirochete and is characterized by edema, synovial thickening, tendonitis and a leukocytic infiltration consisting mainly of neutrophils and mononuclear cells (B rown et al. 1999). In our study, this test was performed in only 7 patients with unclear clinical signs. In the other patients, clinical signs and results of examination were adequately identified for septic arthritis.

The types of bacteria found in our study are commonly reported in septic arthritis in human medicine and small animal literatures (A buekteish et al. 1996; Eg an et al. 1999; Knight et al. 1996; Dubost et al. 2000; Ry an et al. 1997). The major pathogens associated with septic arthritis in our patients are staphylococci, streptococci and Pseudomonas spp. The high proportion and wide range of infections caused by other organisms suggest that the diagnosis of joint infection should be made carefully and that an organism should be sought (Ryan et al. 1997).

Positive results of bacterial culture were found in only 8 patients (45\%). Three of 8 patients, with positive bacterial culture results were the patients with septic arthritis after surgical procedure, and 3 of them were suspected hematogenous route septic arthritis. Septic joint in 1 patient occurred after joint trauma. In another patient it was difficult to define the cause of septic arthritis, because of previous joint operation in 1997 (3 years before presenting clinical signs of septic arthritis). In this case septic joint was associated with endocarditis. We suspected that septic joint occurred from the distribution of bacteria causing endocarditis. The positive rate of synovial fluid cultures found in this study was lower than in other investigations (Egan et al. 1999; B oon 1997; Fink and Nelson 1986; Ry an et al. 1997). However, the negative bacterial culture results are always found in clinical practice due to the method of sampling, methods of bacterial cultivation, the types of transport and culture media selected, and type of bacteria (Boon 1997). Furthermore, many studies also reported that attempts to obtain a bacteriologic diagnosis in the patients with suspected septic arthritis are frequently unsuccessful, and between onethird and two thirds of synovial fluid cultures do not detect the causative organisms (Barton et al. 1987; Fink and Nelson 1986; Goldenberg and Cohen 1976; Welkon et al. 1986). Examination of conventional plates seeded with synovial fluid specimens frequently shows that purulent exudates exert an inhibitory effect upon bacterial growth, which may explain the overall low sensitivity of synovial fluid cultures in the patients with joint infections. It seems natural that blood culture systems in which strategies to overcome the detrimental activity of host defenses are implemented may also prove to be useful for culturing other normally sterile body fluids such as blood culture (Washington and Ilstrup 1986). Innoculation of synovial fluid into large volume of broth or transport media probably dilutes some of these bacterial growth factors, it may influence the bacterial growth culture. Because the inflammatory response in the infected joint space is usually characterized by accumulation of leukocytes in the order of $>10^{5} \cdot \mathrm{ml}^{-1}$ of synovial fluid, we speculated that active phagocytosis might contribute to the failure to recover bacteria noted in a large fraction of patients with septic arthritis. Thus, some methods of bacterial culture such as Isolator 1.5 microbial tube (Yaguosky and Press 1997) may be attempted to increase the sensitivity of bacterial cultures. Recently, Y ag upsky and Press (1997) reported that inoculation of synovial fluid into the Isolator 1.5 microbial tube (Wampole Laboratories, Cranbury, N.J.) improved the recovery of organisms causing 
septic arthritis. This system consists of a tube containing a mixture of saponin, polypropylene glycol, and sodium polyanethole sulfonate that prevents clot formation, causes rapid lysis of erythocytes and leukocyte, and inhibits complement. It has been recognized as a sensitive method for the detection of a wide array of organisms in blood cultures. Furthermore, the blood culture should be done in the patients with hematogenous septic arthritis. Another diagnostic method with higher sensitivity and specificity such as DNA probes and PCR (polymerase chain reaction) should be performed in the complicated patients (Canvin et al. 1997).

Anaerobic bacteria were always overlooked (Hodgin et al. 1992) due to the difficulty of sample collection and cultivation. If concervative methods of treatment with antibiotics do not yield appropriate results, surgical intervention is advocated (Brown and Bennett 1988). In our study, the antibiotic treatment was so effective that surgical treatment was not necessary in any of the patients. Staphylococcus aureus is a major human pathogen and is responsible for infections such as bacterial arthritis. In the past, antibiotics have provided an effective treatment for staphylococcal infection. However, bacteria in general and staphylococci particularly have developed multi-drug resistance. Over the past decades, methicillin resistance in $S$. aureus and Group B Streptococcus infection have become an increasing problem and vancomycin, azithromycin remains the only effective antibiotic (Tis si et al. 1995). Many recent reports were published on successful methods for treating septic arthritis such as gentamicin-impregnated polymethylmethacrylate beads (Brown and Bennett 1988), combination of antibiotics (cloxacillin) and free radical trap ( $\alpha$ phenyl-N-tert-butyl nitrone) which acts as anti-inflammatory and antioxidant (Sakiniene and Collins 2002), treatment with antibiotics and leptin (Hultgren and Tarkowski 2001), and continuous passive motion (CPM) (Lee et al. 2003). We found that each clinical sign and radiographic finding detected in our patients such as mild fever, pain, joint swelling, degree of lameness were not specific to septic arthritis, even though their sensitivities were very high. Therefore, all patients with suspected septic arthritis should be diagnosed by complete diagnostic approach. The combination of diagnostic methods including history, clinical signs, synovial fluid examination associated with radiographic evaluation, should be done to achieve the final diagnosis of septic arthritis.

\section{Septická artritida u psů: retrospektivní studie 20 případů (2000-2002)}

Diagnostika septické artritidy nemusí být vzhledem k nespecifickým klinickým projevům a rentgenologickým nálezům v počátečním stádiu nemoci snadná. Časná diagnostika je důležitá především z pohledu příznivosti prognózy případu. Průkaz septické artritidy byl založen na klinickém, ortopedickém a rentgenologickém vyšetření pacienta, a na vyšetření vzorků synoviální tekutiny (stanovení počtu leukocytů a neutrofilů, cytologickém vyšetření a bakteriální kultivaci). Retrospektivně byly zhodnoceny údaje ve zdravotní dokumentaci 20 případů septické artritidy u 18 psů léčených na Oddělení chirurgie a ortopedie Kliniky chorob malých zviŕat, Veterinární a farmaceutické univerzity Brno v období od ledna 2000 do konce roku 2002.

Pacienti postižení septickou artritidou patřili mezi střední a velká plemena psů. Infekce se $\mathrm{v}$ případě 13 septických artritid u 11 pacientů rozšírila do kloubu hematogenně, zbylých 7 kloubů (u 7 psů) bylo infikováno v průběhu chirurgického zákroku nebo po otevřeném poranění kloubu. Recidiva hematogenní infekce kloubů byla zaznamenána u 2 pacientů. $\mathrm{U}$ všech psů ve sledované skupině byla zaznamenána neochota $\mathrm{k}$ pohybu a bolestivost postiženého kloubu. Kultivace vzorků synoviální tekutiny byla pozitivní pouze v 8 př́ipadech. Izolován byl Staphylococcus intermedius, Streptococcus spp., Enterococcus skupiny 3, Pseudomonas aeruginosa, koaguláza-negativní stafylokokus a Bacillus spp. 
Rentgenologické nálezy zahrnovaly efúzi kloubu, osteoartikulární destrukci a kostní proliferaci a tyto příznaky nebyly pro septickou artritidu specifické.

Zjistili jsme, že diagnostické metody použité v této studii vykazovaly vysokou senzitivitu, avšak nízkou specificitu. Podmínkou správné diagnózy a efektivní léčby septické artritidy je komplexní diagnostický přístup včetně klinického, ortopedického a rentgenologického vyšetření, a také laboratorního vyšetření synoviální tekutiny.

\section{References}

ABUEKTEISH, F, DAOUD, AS, MESMAR, M, OBEIDAT, A 1996: Nosocomial neonatal septic arthritis. Eur J Pediatr 155: 102-105

BARANYIOVÁ, E, HOLUB, A, MARTINÍKOVÁ, M, NEČAS, A, ZATLOUKAL, J 2003: Epidemiology of Intraspecies Bite Wounds in Dogs in the Czech Republic.Acta Vet Brno 72: 55-62

BARTON, LL, DUNKLES, LM, HABIB, FH 1987: Septic arthritis in childhood. A 13-year review. Am J Dis Child 141: $898-900$

BENNETT, D, TAYLOR, DJ 1987: Bacterial endocarditis and inflammatory joint disease in the dog. J Small Anim Pract 29: 347-365

BENNETT, D, TAYLOR, DJ 1988: Bacterial infective arthritis in the dog. J Small Anim Pract 29: 207-230

BITTEGEKO, SBP, ARNBJERK, J, HEJE, NI 1993: Infectious epiphysitis and arthritis in a puppy. J Small Anim Pract 34: 571-575

BITTINI, A, DOMINGUEZ, PL, MARTINEZ PUEYO, ML 1985: Comparison of bone and gallium-67 imaging in heroin user's arthritis. J Nuclear Med 26: 1377-1381

BOON, D 1997: Synovial fluid analysis: A guide for small animal practitioners. Vet Med 92: 443-451

BROWN, A, BENNETT, D 1988: Gentamicin-impregnated polymethymethacrylate beads for the treatment of septic arthritis. Vet Rec 123: 625-626

CANVIN, JMG, GOUTCHER, SC, HAGIG, M, GEMMEL, CG, STURROCK, RD 1997: Persistance of Staphylococcus aureus as detected by polymerase chain reaction in the synovial fluid of a patient with septic arthritis. Br J Rheum 36: 203-206

CORSTENS, HM, VAN DER MEER, WM 1999: Nuclear medicine's role in infection and inflammation. The Lancet 354: 765-770

COWELL, RL, TYLOR, RD, CLINKENBEARD, KD, MEINKOTH, JH 1988: Ehrlichiosis and polyarthritis in three dogs. J Am Vet Med Assoc 192: 1093-1095

DVOŘÁK, M, NEČAS, A, ZATLOUKAL, J 2000: Complications of long bone fracture healing in dogs: functional and radiological criteria for their assessment. Acta vet Brno 69: 107-114

DUBOST, JJ, SOUBRIER, M, SAUVEZIE, B 2000: Pyogenic arthritis in adults. Joint Bone Spine 67: 11-21

EGAN, SG, LASALLE, MD, STOCK, JA, HANNA, MK 1999: Septic arthritis secondary to vesicoureteral reflux into ectopic ureter. Pediart Nephrol 13: 932-933

FINK, CW, NELSON, JD 1986: Septic arthritis and osteomyelitis in children. Clin Rheum Dis 12: 423-435

GÁL, P, NEČAS, A 1999: Mininvazivní osteosyntéza při poranění laterální fýzy kondylu humeru u dětí. LEK OBZ 48: $145-148$

GIBSON, NR, CARMICHAEL, S, LI, A 1999: Value of direct smears of synovial fluid in the diagnosis of canine joint diseases. Vet Rec 144: 463-465

GOLDENBERG, DL, COHEN, AS 1976: Acute infectious arthritis. A review of patients with nongonococcal joint infections (with emphasis on therapy and prognosis). Am J Med 60: 369-377

GOLDENBERG, DL, REED, JI 1985: Bacterial arthritis. N Eng J Med 312: 764-771

GUTHRIE, S, PLUMMER, JM, VAUGHAN, LC 1992: Etiopathogenesis of canine elbow osteochondrosis: A study of loose fragments removed at arthrotomy. Res Vet Sci 52: 284-291

HODGIN, EC, MICHAELSON, F, HOWERTH, EW, AUSTIN, F, DAVIS, F, HAAS, AS 1992: Anaerobic bacterial infections causing osteomyelitis/arthritis in a dog. J Am Vet Med Assoc 201: 886-888

HULSE, D, NEČAS, A 2002: Komplikace při dlahování končetin. Sborník praktického kurzu s mezinárodní účastî „Dlahování končetin, závěsy, bandáže a rehabilitace u pacientů s ortopedickými problémy, Brno, 7.-8.září, pp. 41-42

HULTGREN, O, KOPF, M, TARKOWSKI, A 1998: Staphylococcus aureus-Induced Septic Arthritis and Septic Death Is Decreased in IL-4 Deficient Mice: Role of IL-4 as Promoter for Bacterial Growth. J Immunology 160: 5082-5087

HULTGREN, O, TARKOWSKO, A 2001: Leptin in septic arthritis: decreased levels during infection and amelioration of disease activity upon its administration. Arthritis Research 3: 389-394

JACQUES, D, CAUZINILLE, L, BOUVY, B, DUPRE, G 2002: A Retrospective study of 40 Dogs with Polyarthritis. Vet Surg 31: 428-434

KNIGHT, DJ, GILBERT, FJ, HUTCHISON, JD 1996: Lesson of the Week: Septic arthritis in osteoarthritic hips. B Med J 313: 40-41

LAHO, K, KOTILAINEN, P 2001: Septic arthritis due to Prevotella bivia after intraarticular joint injection. Joint Bone Spine 68: $443-444$ 
LEE, MS, IKENOUE, T, TRINDADE, MCD, WONG, N, GOODMAN, SB, SCHURMAN, DJ, SMITH, RL 2003 : Protective effects of intermittent hydrostatic pressure on osteoarthritic chondrocytes activated by bacterial endotoxin in vitro. J Orthop Res 21:117-122

LIU, ZQ, DENG, GM, FOSTER, S, TARKOWSKI, A 2001: Staphylococcus peptidoglycans induced arthritis. Arthritis Research 3: 375-380

MARCHEVSKY, AM, READ, RA 1999: Bacterial septic arthritis in 19 dogs. Aust Vet J 77: 233-237

MAY, SA 1995: Guest editorial, Infectious agents and joint diseases. Br Vet J 151: 229-232

MCINNES, IB, LEUNG, B, WEI, XQ, GEMMEL, CC, LIEW, FY 1998: Septic Arthritis Following Staphylococcus aureus Infection in Mice Lacking Inducible Nitric Oxide Synthase. J Immunology 160: 308-315

NEČAS, A, DVOŘAK, M, ZATLOUKAL, J 1999: Incidence of Osteochondrosis in Dogs and Its Late Diagnosis. Acta vet Brno 68: 131-139

NEČAS, A, SRNEC, R, KECOVÁ, H 2002: Diagnostic reliability of stifle arthroscopy of pathological changes in cruciate deficient knee. Acta Vet Brno 71: 249-254

NEČAS, A, TOOMBS, JP, JOHNSON, AL 1998: Zevní skeletní fixace a biologická léčba fraktur. Vector, pp. $137-$ 143

NEČAS, A, ZATLOUKAL, J 2001: Současné trendy v konzervativní léčbě osteoartritidy u psů. Veterinářství 51 343-350

NEČAS, A, ZATLOUKAL, J 2002: Factors related to the risk of meniscal injury in dogs with cranial cruciate ligament rupture. Acta Vet Brno 71: 77-84

NECAAS, A, ZATLOUKAL, J, KECOVÁ, H, DVOŘÁK, M 2000: Predisposition of dog breeds to rupture of the cranial cruciate ligament. Acta Vet Brno 69: 305-310

OLSSON, SE 1993: Pathophysiology, morphology, and clinical signs of osteochondrosis in the dog. In: BOJRAB, MJ (Ed): Disease mechanisms in small animal surgery. Lea \& Febiger, Philadelphia, pp. 777-796

OWEN, JM, ACKERMAN, N 1978: Roentgenology of Arthritis. Vet Clin North Am 8: 453-464

PEDERSON, NC, POOL, R 1978: Canine joint disease. Vet Clin North Am 8: 465-510

PEREZ, LC 1999: Septic arthritis. Bailliere's Clinical Rheumatology 13: $37-58$

PIERMATTEI, DL, FLO, GL 1997: Arthrology. In: PIERMATTEI, DL, FLO, GL (Ed): Brinker, Piermattei and Flo's Handbook of Small Animal Orthopedics and Fracture repair. 3rd ed., W.B.Saunder, p. 743

ROUSH, JK, MANLEY, PA, DUELAND, RT 1989: Rheumatoid arthritis subsequent to Borrelia burgdoferi infection in two dogs. J Am Vet Med Assoc 195: 951-953

RYAN, MJ, KAVANAGH, R, WALL, PG, HAZELMAN, BK 1997: Bacterial joint infectons in England and Wales: analysis of bacterial isolates over a four-year period. Br J Rheum 36: 370-373

SAKINIENE, E, COLLINS, LV 2002: Combined antibiotic and free radical trap treatment is effective at combating Staphylococcus aureus-induced septic arthritis. Arthritis Research 4: 196-200

SCHRADER, SC 1982: Septic arthritis and osteomyelitis of the hip in six mature dogs. J Am Vet Med Assoc 181: 894-898

STROUSE, PJ, LONDY, F, DIPIETRO, MA, TEO, EHJ, CHRISP, CE, DOI, K 1999: MRI evaluation of infectious and non infectious synovitis: preliminary studies in a rabbit model. Pediatr Radiol 29: 367-371

TISSI, L, VON HUNOLSTEIN, C, MOSCL, P, CAMPANELLI, C, BISTONI, F, OREFICI, G 1995: In vivo Efficacy of azithromycin in treatment of systemic infection and septic arthritis induced by Type IV group B streptococcus strains in mice: comparative study with erythromycin and penicillin G Antimicrob Chemother 39: 1938-1947

TOOMBS, JP, NEČAS, A 1999: Rentgenologické vyšetření psa s dysplazií kyčelního kloubu. In: NEČAS, A, TOOMBS, J P: Dysplazie kyčelního kloubu u psů. Artron s.r.o., Brno, pp. 17-26

WASHINGTON, JA, ILSTRUP, DM 1986: Blood cultures:issues and controversies. Rev Infect Dis 5: 792-802

WELKON, CJ, LONG, SS, FISHER, MC, ALBURGER, PD 1986: Pyogenic arthritis in infants and children: a review of 95 cases. Pediatr Infect Dis 5: 669-676

WIND, AP 1993: Elbow dysplasia. In: SLATTER, D (Ed): Textbook of Small Animal Surgery. 2nd ed. W. B. Saunders, Philadelphia, pp. 1966-1977

YAGUPSKY, P, PRESS, J 1997: Use of the Isolator 1.5 Microbial Tube for Culture of Synovial Fluid from Patients with Septic Arthritis. J Clin Microbiol 35: 2410-2412

ZATLOUKAL, J, NEČAS, A, DVOŘÁK, M 2000: Measuring craniocaudal instability in stifle joints of dogs using stress radiographs. Acta Vet Brno 69: 311-317 